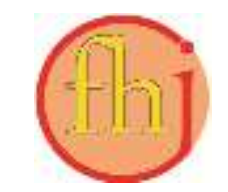

Faletehan Health Journal, 8 (2) (2021) 71-76

www. journal.Ippm-stikesfa.ac.id/ojs/index.php/FHJ

ISSN 2088-673X | e-ISSN 2597-8667

\title{
Perbedaan Efektifitas Metode Ceramah dan Media Video dalam Meningkatkan Pengetahuan Pembelajaran Praktikum Keperawatan
}

\author{
Agus Sustiyono ${ }^{1 *}$ \\ ${ }^{1}$ Fakultas Ilmu Kesehatan, Universitas Faletehan \\ *Corresponding Author: agussustiyono.nazwa@gmail.com
}

\begin{abstract}
Abstrak
Diantara banyak teknologi pembelajaran, media video memiliki lebih banyak keuntungan. Pemutaran video dapat menggambarkan objek atau suatu proses secara tepat dan menyajikan keterampilan yang diajarkan secara berulangulang. Video memiliki kemampuan dalam memanipulasi waktu dan ruang dan dapat mengajak peserta melihat berbagai ukuran objek serta peristiwa dimana saja. Penelitian ini bertujuan untuk mengetahui pengaruh media video dalam meningkatkan pengetahuan mahasiswa tingkat I Program Studi Diploma III Keperawatan Universitas Faletehan Serang pada pembelajaran praktikum keperawatan. Desain penelitian ini menggunakan eksperimen semu (quasi experimental) dengan rancangan non-equivalent two groups design. Sampel penelitian adalah mahasiswa tingkat I Program Studi Diploma III Keperawatan sebanyak 96 orang yang dibagi menjadi 2 kelompok. Kelompok 1 mendapatkan perlakuan metode ceramah sebanyak 48 mahasiswa dan kelompok 2 mendapatkan perlakuan media video sebanyak 48 mahasiswa. Hasil penelitian menunjukkan peningkatan nilai mean pengetahuan sebanyak 0,29 pada kelompok perlakuan metode ceramah dan 2,21 pada kelompok perlakuan media video. Hasil penelitian juga menunjukkan terdapat perbedaan pengetahuan yang signifikan $(p=0,000)$. Kesimpulan penelitian ini adalah terdapat perbedaan efektifitas pembelajaran antara metode ceramah dengan pembelajaran berbantuan media video terhadap pengetahuan mahasiswa pada pembelajaran praktikum keperawatan.
\end{abstract}

Kata Kunci: Media Video, Pengetahuan Mahasiswa, Praktik Keperawatan

\section{Effectiveness Difference of Lecture Method and Video Use in Increasing Knowledge of Nursing Practice Learning}

\begin{abstract}
Among learning technologies, video has more advantages. Video play can describe an object or a process correctly and present taught skills repeatedly. Video is able to manipulate time and space and can invite participants to see various sizes of object and events anywhere. This study aims to determine the effects of video to increase the knowledge of first level students at Diploma III Nursing Study Program of Faletehan University Serang in nursing practices. The design of this research is quasi experimental with non-equivalent two groups design. The research samples were 96 first level students at Diploma III Nursing Study Program, which were divided into 2 groups. Group 1 received lecture treatment as many as 48 students and group 2 received video treatment as many as 48 students. The results showed the increase of knowledge mean score as much as 0.29 in the lecture treatment group and 2.21 in the video treatment group. The results also showed a significant difference of knowledge $(p=0.000)$. To conclude, there is a difference in the effectiveness of learning between lecture method and video-use on student knowledge in nursing practice.

Keywords: Video Media, Student Knowledge, Nursing Practices
\end{abstract}




\section{Pendahuluan}

Proses pembelajaran di Perguruan Tinggi merupakan suatu sistem yang harus dapat menumbuhkan kemampuan seorang mahasiswa dalam menyerap pemahaman materi pembelajaran secara keseluruhan khususnya pembelajaran praktikum. Untuk menunjang keberhasilan dan hasil belajar siswa dalam proses pembelajaran praktikum, dosen memerlukan sarana guna dapat menyampaikan materi dengan baik maupun menarik sehingga dapat dipahami oleh peserta didiknya. Pembelajaran yang berkualitas akan memperoleh hasil belajar mahasiswa yang maksimal. Pembelajaran merupakan perubahan dalam kepribadian yang perwujudan sebagai polapola respons baru yang berbentuk keterampilan, sikap, kebiasaan, pengetahuan dan kecakapan (Rusman, 2012).

Diantara banyak teknologi pembelajaran salah satunya adalah media video. Media video memiliki lebih banyak keuntungan. Pemutaran video dapat menggambarkan objek atau suatu proses secara tepat, mengajarkan ketrampilan yang dapat disajikan secara berulang-ulang. Sanjaya (2007) menerangkan bahwa video mempunyai kelebihan dapat digunakan sebagai alat bantu pendidikan secara luas. Video mempunyai kemampuan memanipulasi waktu dan ruang, dapat mengajak peserta melihat peristiwa dimana saja serta berbagai ukuran objek. Pemutaran video dalam pendidikan dapat membangkitkan emotional intelegence audience bagi yang menontonnya dan meningkatkan daya pikir peserta (Berk, 2009). Oleh karena itu, maka penggunaan suatu metode yang disertai media dalam pembelajaran secara tepat akan memberikan hasil pembelajaran yang lebih optimal (Harsono, 2009).

Hasil belajar peserta didik dipengaruhi oleh berbagai faktor, seperti motivasi belajar, metode pengajaran, sarana dan prasarana yang berupa media pembelajaran. Motivasi belajar merupakan kekuatan (power motivation), daya pendorong (driving force) atau alat pembangun kesediaan dan keinginan yang kuat dalam diri siswa untuk belajar secara aktif, kreatif, efektif, inovatif, dan menyenangkan dalam rangka perubahan perilaku, baik dalam aspek kognitif, afektif maupun psikomotor. Hal diatas sejalan dengan apa yang telah dikemukakan oleh Lukmanulhakim., \& Pusporini, (2018) bahwa beberapa faktor prestasi hasil belajar yang dipengaruhi oleh dua faktor yaitu faktor internal dan faktor eksternal. Faktor internal yaitu faktor yang berasal dari dalam diri siswa yang terdiri dari faktor psikologis (inteligensi, sikap, bakat, minat, dan motivasi), dan faktor fisiologis (sakit atau cacat tubuh). Faktor eksternal yaitu faktor yang berasal dari luar diri siswa yang meliputi lingkungan sosial (orangtua/keluarga). Selain itu, keaktifan mahasiswa dalam pembelajaran merupakan hal yang perlu diperhatikan mahasiswa dalam upaya mencapai prestasi belajar yang optimal. Mahasiswa yang belajarnya aktif dan memiliki motivasi yang tinggi akan mampu mencapai prestasi belajar yang tinggi. Mahasiswa yang memiliki motivasi belajar tinggi serta tekun baik secara kogitif, afektif maupun psikomotor. Mahasiswa tersebut cenderung akan lebih menguasai konsep keperawatan yang nantinya akan diterapkan kepada masyarakat (Lukmanulhakim., \& Pusporini., 2018).

Peran dosen dalam pengelolaan pembelajaran adalah merencanakan pengajaran, dan memiliki pendekatan metode belajar-mengajar, dan asasasas didaktik (Suprijono, 2010). Melalui penerapan metode pembelajaran dosen dapat membantu peserta didik mendapatkan informasi, ide, keterampilan, cara berfikir, dan mengekspresikan ide dalam proses pembelajaran. Metode pembelajaran berfungsi pula sebagai pedoman bagi para perancang pembelajaran para dosen dalam merencanakan pembelajaran.

Dimasa sekarang teknologi dalam pembelajaran bisa menjadi sarana pembelajaran, media, dan sumber belajar bagi siswa. Sebagai sumber belajar, teknologi pengembangan media pembelajaran merupakan alat untuk memperlancar pemahaman pembelajaran yang lebih menarik bagi siswa, sehingga dimungkinkan pula dapat memperoleh hasil belajar yang sesuai dengan harapannya.

Penelitian ini bertujuan untuk mengetahui pengaruh media video untuk meningkatkan pengetahuan pembelajaran praktikum keperawatan pada mahasiswa tingkat I Program Studi D III Keperawatan Sekolah Tinggi Ilmu Kesehatan Faletehan Serang, Banten.

\section{Metodologi Penelitian}

Desain penelitian ini menggunakan eksperimen semu (quasi experimental) dengan rancangan yang digunakan adalah non equivalent two groups design, yaitu kelompok intervensi 
Faletehan Health Journal, 8 (2) (2021) 71-76

pertama menerima perlakuan (X1), kemudian dilakukan pengukuran pre dan post test. Hasil observasi ini dibandingkan dengan hasil observasi pada kelompok intervensi kedua yang menerima perlakuan (X2) dengan terlebih dahulu dilakukan pengukuran pre dan post test. Sampel penelitian adalah mahasiswa tingkat I Program Studi Diploma III Keperawatan sebanyak 96 orang. Sampel dalam penelitian ini terdiri dari kelompok intervensi yang menerima perlakuan pemberian pembelajaran dengan metode ceramah sebanyak 48 orang dan satu kelompok intervensi yang menerima perlakuan pemberian pembelajaran dengan metode media video sebanyak 48 orang. Variabel bebas dalam penelitian ini adalah media pembelajaran (ceramah dan pemutaran video) sedangkan variabel terikat penelitian adalah pengetahuan.

Pada penelitian ini, peneliti terlebih dahulu melakukan pre test yaitu mengukur tingkat pengetahuan mahasiswa, kemudian memberikan intervensi kepada responden berupa pembelajaran dengan ceramah pada kelompok 1 dan pada kelompok 2 berupa pemutaran video demonstrasi tentang praktik terapi pemasangan infus di kelas. Selanjutnya melakukan post test yaitu dengan mengukur kembali tingkat pengetahuan mahasiswa.

Teknik analisis data menggunakan analisa univariat dan analisa bivariat. Analisa univariat digunakan untuk mengetahui distribusi frekuensi pengetahuan sebelum dan sesudah pemberian tindakan pemutaran video dengan menggunakan rumus mean. Analisa bivariat menggunakan uji statistik uji T (T-test) yaitu uji beda dua mean independen.

\section{Hasil dan Pembahasan}

Umur responden dalam penelitian ini adalah umur mahasiswa yang terhitung antara 19 sampai 21 tahun. Usia pada kedua kelompok intervensi termasuk pada tahap dewasa. Usia dewasa merupakan tahap seseorang mencapai kematangan fisik dan psikososial, dan kognitif. Individu yang dewasa merasa nyaman dengan kemampuan dan pengetahuan yang dimiliki, terbuka menerima saran dan kritik, berusaha menyelesaikan masalah, serta mau mengambil keputusan terhadap masalah yang dihadapi (Potter, P.A, Perry, 2005). Pemilihan usia ini dengan harapan proses pembelajaran yang diberikan kepada responden akan dapat diterima secara efektif dan maksimal.

Sebagian besar responden merupakan mahasiswa tingkat I yang masih belum terpapar secara luas terhadap materi tindakan-tindakan keperawatan. Pengalaman pendidikan dapat meningkatkan pengaruh terhadap proses penyampaian dan penerimaan pesan (Potter., \& Perry, 2005). Pengetahuan sangat memengaruhi seseorang, tingkat pengetahuan berkaitan erat dengan tingkat pendidikan dan informasi yang didapat seseorang (Hanifah, Nanang, \& Suhana, 2012). Semakin tinggi tingkat pendidikan seseorang akan semakin mudah dalam menerima dan mengolah pesan yang diterima.

Perbedaan pengetahuan pada kelompok intervensi 1 dan kelompok intervensi 2

Tabel 2: Perbedaan total skor pengetahuan pada kelompok intervensi 1 dan kelompok intervensi 2

\begin{tabular}{cccc}
\hline $\begin{array}{c}\text { Kelompok variabel } \\
\text { pengetahuan }\end{array}$ & Mean & SD & P-value \\
\hline Ceramah & 11,23 & 1,57 & 0 \\
\hline Video & 13,21 & 1,30 & 0,000 \\
\hline
\end{tabular}

Tabel 1. Perbedaan total skor pengetahuan pre dan post test pada kelompok intervensi 1 dan kelompok intervensi 2

\begin{tabular}{ccccccccc}
\multirow{2}{*}{$\begin{array}{c}\text { Kelompok variabel } \\
\text { pengetahuan }\end{array}$} & \multicolumn{2}{c}{ Pre test } & \multicolumn{2}{c}{ Post test } & Selisih & $\begin{array}{c}\text { Hasil uji t dependen } \\
(p \text {-value })\end{array}$ \\
\cline { 2 - 7 } & Mean & SD & Mean & SD & Mean & SD & \\
\hline Ceramah & 10,94 & 1,64 & 11,23 & 1,57 & 0,29 & 0,74 & $0,01^{\mathrm{a}}$ \\
\hline Video & 11,00 & 1,46 & 13,21 & 1,30 & 2,21 & 0,41 & $0,00^{\mathrm{a}}$ \\
\hline \multicolumn{4}{c}{$p$ value uji beda selisih mean } & & $1,92^{\mathrm{b}}$ & & \\
\hline
\end{tabular}

Ket : SD : Standar Deviasi

a) : nilai $p$ tidak berdistribusi normal dan dihitung menggunakan Wilcoxon

b) : nilai $p$ tidak berdistribusi normal dan dihitung menggunakan mann-whitney 
Pada kelompok dengan metode pembelajaran dengan metode ceramah terjadi peningkatan nilai mean pengetahuan yaitu sebelum diberikan materi pembelajaran sebesar 10,94 dan setelah diberikan pembelajaran menjadi 11,23 dengan nilai $\mathrm{p}$ value 0,01, sehingga dapat diartikan bahwa terdapat perbedaan pengetahuan pada kelompok metode pembelajaran ceramah antara sebelum dan sesudah diberikan pembelajaran. Kelompok yang mendapat perlakuan metode pembelajaran menggunakan media video terjadi peningkatan nilai mean pengetahuan yaitu sebelum diberikan pembelajaran sebesar 11,00 dan setelah diberikan pembelajaran menjadi 13,21 dengan nilai $p$ value 0,00 , sehingga dapat diartikan bahwa terdapat perbedaan pengetahuan yang signifikan pada kelompok pembelajaran dengan media video antara sebelum dan sesudah diberikan pembelajaran.

Hasil penelitian menunjukkan peningkatan nilai mean pengetahuan sebanyak 0,29 pada kelompok intervensi ceramah dan 2,21 pada kelompok intervensi dengan media video. Hasil penelitian juga menunjukkan terdapat perbedaan pengetahuan yang signifikan $(P=0,000)$. Sehingga dapat diartikan bahwa terdapat perbedaan pengetahuan yang signifikan pada kelompok pembelajaran dengan media ceramah dengan pembelajaran menggunakan media video. Hasil penelitian ini sejalan dengan penelitian sebelumnya yang menyebutkan bahwa tingkat pengetahuan seseorang setelah diberikan pendidikan dengan media video akan mengalami peningkatan (Hanifah, 2015).

Proses pembelajaran melalui metode ceramah yang diberikan kepada mahasiswa mampu meningkatkan tingkat pengetahuan siswa (Rohima \& Marthia, 2018). Tetapi pada kondisi dimana materi pembelajaran melibatkan suatu tahapantahapan kegiatan yang membutuhkan daya imajinasi siswa untuk memahami dengan mencerna dan menggambarkanya maka bentuk intervensi pembelajaran dengan metode ceramah akan memberikan hasil pemahaman pengetahuan yang kurang maksimal, contohnya seperti pada proses pembelajaran yang bersifat tindakan pemasangan infus dalam ilmu keperawatan. Konsep pemahaman mahasiswa terbatas pada konsep yang diterangkan oleh dosen saja, tetapi mahasiswa masih sulit dalam memahami penjelasan terahadap tahapan-tahapan tindakan yang dilalui dari tindakan tersebut. Mahasiswa tidak tergambarkan dengan jelas tentang perasat yang sudah dijelaskan

Pembelajaran dengan media video mempunyai kemampuan dalam memanipulasi waktu dan ruang dapat mengajak audience untuk melihat peristiwa dimana saja walaupun dibatasi dengan ruang. Objek-objek yang terlalu kecil, terlalu besar, berbahaya atau bahkan tidak dapat dikunjungi oleh audience dapat dihadirkan melalui media video. Video dapat menggambarkan suatu objek yang bergerak bersama-sama dengan suara alamiah atau suara yang sesuai, video melukiskan gambar hidup dan suara yang memberinya daya tarik tersendiri terhadap audience.

Rani (2013) dalam penelitiannya menjelaskan bahwa penggunaan media video pada proses pembelajaran ditemukan peningkatan terhadap pengetahuan setelah proses pembelajaran dilakukan evaluasi (Rani, 2013). Penelitian lain juga menjelaskan bahwa siswa yang mendapatkan perlakuan pembelajaran praktikum dengan menyaksikan video terbukti secara signifikan mampu meningkatkan pengetahuan (Shorayasari, Effendi, \& Puspita, 2017). Kedua penelitian ini menjelaskan bahwa pembelajaran yang dilakukan dengan menggunakan media video akan meningkatkan tingkat pengetahuan terhadap materi pembelajaran khususnya yang bersifat tindakan.

Selain pemutaran video, metode pembelajaran juga dapat menggunakan modifikasi antara video dengan teknologi interaktif sehingga pada proses pembelajaran dapat terjadi interaksi yang aktif antara dosen dengan mahasiswa. Teknologi interaktif merupakan media berbasis komputer yang memungkinkan pengguna untuk mengakses informasi dan layanan yang menarik, mengendalikan bagaimana informasi disajikan, dan menanggapi informasi dan pesan dalam lingkungan yang dimediasi (misalnya, menjawab pertanyaan, mengirim pesan, mengambil aksi dalam game, menerima umpan balik atau respons terhadap aksi sebelumnya) (L, Jr, Gold, \& Manning, 1997).

Responden dapat meningkatkan pengetahuan melalui berbagai metode dan media, seperti hasil penelitian sebelumya yang menyatakan bahwa penggunaan media film sebagai media pembelajaran yang dapat digunakan untuk meningkatkan pengetahuan responden (Pertiwi \& Annissa, 2019). Keterpaparan media juga 
Faletehan Health Journal, 8 (2) (2021) 71-76 www. journal.Ippm-stikesfa.ac.id/ojs/index.php/FHJ ISSN 2088-673X | 2597-8667

berdampak pada tingkat pengetahuan responden, semakin sering responden terpapar media pembelajaran akan mengingkatkan pengetahuan. Dosen dalam pengembangan media pembelajaran juga dapat merujuk dan memanfaatkan media film atau video yang ada di jaringan internet. Beberapa penelitian menunjukkan bahwa media pembelajaran melalui internet merupakan salah satu media yang paling banyak di akses oleh masyarakat mulai dari level dasar sampai masyarakat dengan tingkat pendidikan tinggi khususnya yang terkait dengan media video karena dianggap dapat memberikan pemahaman yang lebih baik (Andriani, Yasnani, \& Arum, 2016).

Proses pembelajaran yang akan dilakukan dengan tujuan ingin meningkatkan kemampuan mahasiswa dalam memahami konsep seperti pada tindakan keperawatan yang diajarkan, maka proses pembelajaran tidak cukup hanya dengan metode ceramah saja, mahasiswa harus diberikan metode lain yang dapat memberikan gambaran tentang proses atau tahapan tindakan yang harus mereka pahami, maka metode pembelajaran dengan media video bisa menjadi salah satu pilihan sebagai metode pembelajaran yang diberikan.

\section{Simpulan}

Kesimpulan dari penelitian ini adalah terdapat perbedaan efektifitas pembelajaran antara metode ceramah dengan metode pembelajaran berbantuan media video terhadap pengetahuan. Pembelajaran dengan menggunakan media video, hasil penelitian menunjukan perbedaan hasil yang lebih signifikan dibandingkan dengan metode ceramah. Pembelajaran pada mata ajar praktikum dengan materi tindakan keperawatan seperti perasat pemasangan infus akan mendapatkan hasil yang lebih baik pada pengetahuan bila menggunakan media pembelajaran berbantuan media video.

\section{Referensi}

Andriani, H., Yasnani, \& Arum. (2016). Hubungan Pengetahuan, Akses Media Informasi dan Peran Keluarga Terhadap Perilaku Seksual Pada Siswa SMK Negeri 1 Kendari Tahun 2016. Kendari.

Berk, R. . (2009). Multimedia Teaching with Video Clips: TV, Movies, Youtube and MTV in the College Classroom. International Journal of Technology in Teaching and Learning.

HANIFAH, D. L. (2015). Perbedaan Pengetahuan Remaja Sebelum Dan Sesudah Diberikan
Penyuluhan Gizi Seimbang Dengan Menggunakan Media Video Di Smp Negeri 2 Kartasura. Surakarta : Unimus Surakarta.

Hanifah, Nanang, \& Suhana, C. (2012). Konsep Strategi Pembelajaran. Bandung: Refika Aditama.

Harsono, B. S. . (2009). Perbedaan Hasil Belajar Antara Metode Ceramah Konvensional dengan Ceramah Berbantuan Media Animasi pada Pembelajaran Kompetensi Perakitan dan Pemasangan Sistem Rem. Jurnal PTM, 9(2).

Lukmanulhakim, L., \& Pusporini, L. (2018). The Analysis of Factors Influencing Graduation Achievement in Nurse Competence Test of Nurse Profession Program. Jurnal Cakrawala Pendidikan, $37(2)$. doi:https://doi.org/10.21831/cp.v37i2.19881

L, R., Jr, S., Gold, W. R., \& Manning, T. (1997). Health Promotion and Interactive Technology. New York and London: Routledge. Retrieved from http://www.ghbook.ir/index.php?name=فر هن

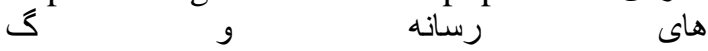
نوين\&option=com_dbook\&task=readonline\& book_id=13650\&page $=73 \&$ chkhashk=ED9C 9491B4\&Itemid $=218 \&$ lang $=$ fa\&tmpl=compo nent

Pertiwi, W. E., \& Annissa, A. (2019). the Evaluation of Health Promotion Media Availability in Elementary Schools. Jurnal PROMKES, $\quad 7(1), \quad 100$. https://doi.org/10.20473/jpk.v7.i1.2019.100104

Potter, P.A, Perry, A. G. (2005). Fundamental Keperawatan: Konsep, Proses, Dan Praktik.Alih Bahasa : Yasmin Asih, dkk. (Edisi 4.Vo). Jakarta: EGC.

Rani, P. (2013). Effect of Video-Assisted Teaching on Knowledge of Family Welfare Measures among Primigravidae in Kanyakumari District. Pudukkottai (TN), NJI-OCT.

Rohima, E. I., \& Marthia, N. (2018). Penerapan Program Penyuluhan Pada Pembinaan Perilaku Hidup Bersih dan Sehat (PHBS) pada Anak Masa Puber di Tingkat Sekolah Dasar. INFOMATEK, 20(1). https://doi.org/http://dx.doi.org/10.23969/info matek.v20i1.879

Rusman. (2012). Model-model Pembelajaran: Mengembangkan Profesionalisme Guru. Jakarta: RajaGrafindo Persada.

Sanjaya, W. (2007). Strategi Pembelajaran 
Faletehan Health Journal, 8 (2) (2021) 71-76

www. journal.Ippm-stikesfa.ac.id/ojs/index.php/FHJ

ISSN 2088-673X | 2597-8667

Berorientasi Standar Proses Pendidikan. Jakarta: Kencana.

Shorayasari, S., Effendi, D. P., \& Puspita, S. (2017). Perbedaan Pengetahuan Setelah diberikan Pendidikan Kesehatan tentang Menggosok Gigi dengan Video Modeling. Jurnal Ilmu Kesehatan Masyarakat, 8(10), 43-48.

Suprijono, A. (2010). Cooperative Learning. Yogjakarta: Pustaka Media. 